\title{
A Cross-cultural Analysis of Management Approaches in Comparison to Turkish and Swiss Companies
}

\author{
Erdem Erciyes
}

Strategy Department of the Turkish Gendarmerie, Ankara, Turkey

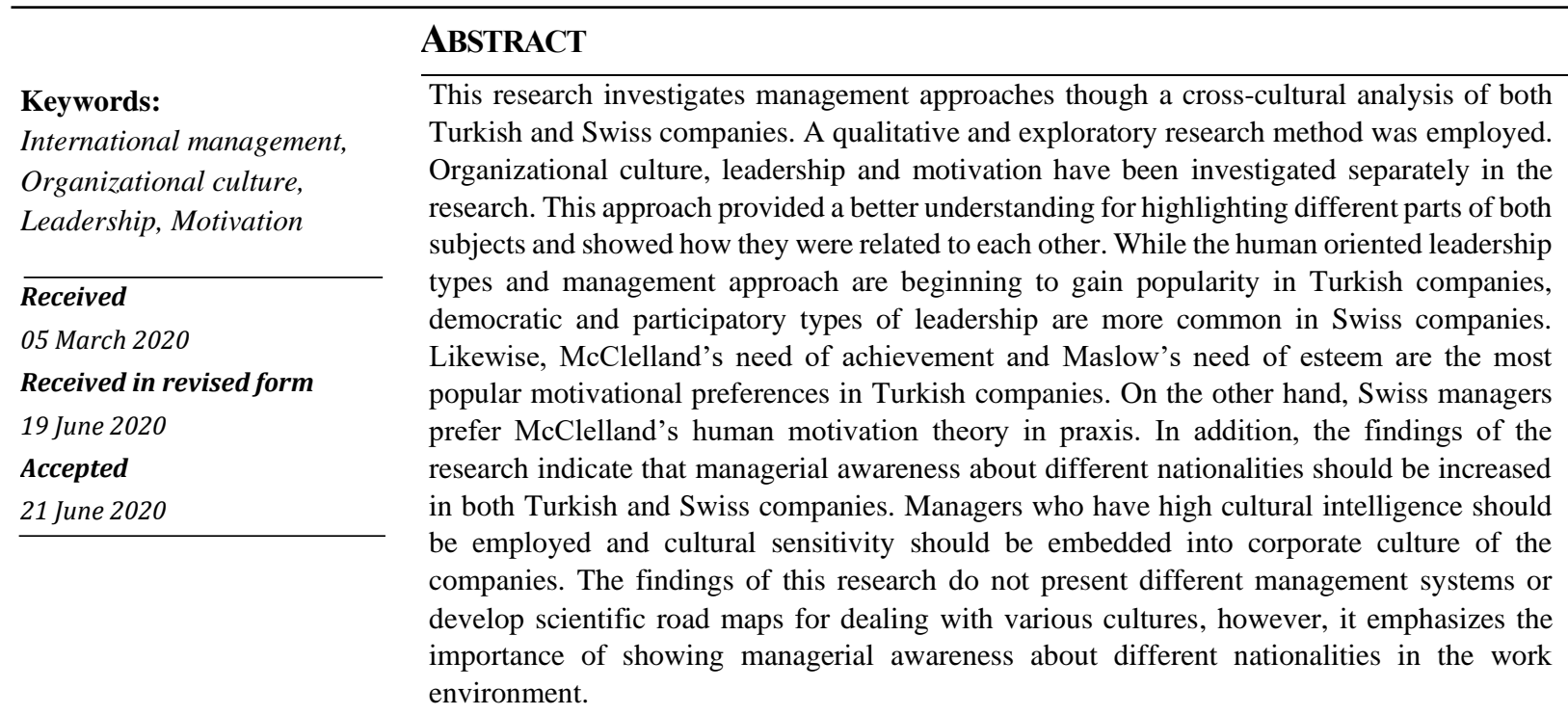

Correspondence:

\section{Introduction}

Starting with the process of the demise of the Soviet Union, physical and mental borders between countries were removed and due to burgeoning unions such as the European Union, the North American Free Trade Agreement (NAFTA) and the Shanghai Cooperation Organization (SCO), cultural transactions in business environments became more common (Lukin, 2019). Many employees chose to work at organizations and companies in foreign countries. In this context, understanding cultural differences gained more importance for managers. The starting point of this 
study is the need for managers who want to manage their multinational teams in an efficient and scientific way.

Only a few research (Bartsch, Ebers, \& Maurer, 2013; Hamden-Turner \& Trompenaars, 2004; Hofstede, 2001; Schwartz, 1999) attempt to identify the cross-cultural relation of management approaches in the axis of motivation, leadership and culture in the existing literature. This area appears to have received little attention in the past. In order to provide a deeper understanding for the inquiry, empirical constituents of grand theories of such as culture, leadership, and motivation will be examined separately for Turkish and Swiss companies.

The Turkish economy has shown remarkable growth in the last decade. Turkey aims to sustain economic growth and to be included within the top ten economies in the world by 2023 (Presidency of Strategy \& Budged, 2019). In parallel with this growth, Turkish companies started to open up abroad and began to increase their market share in the international area. Most of the Turkish companies transformed into multi-national companies and became the center of attraction for foreign employees. Nowadays, it is quite common to see foreign employees and multinational teams in Turkish companies (Kurosawa, 2018). To this effect, Turkish companies began to face a source of labor from different cultures. However, this cultural diversity also brought some administrative difficulties. Multinational teams are completely a new situation for Turkish companies. In order to survive in the brutal working conditions, it is very crucial for them to succeed in the management of their employees. Managing multi-culturally is a new phenomenon for Turkish managers and the researcher believes their inexperience will bring a different and fresh perspective on the multi-cultural work force. Hence, Turkish managers were chosen as part of this cross-cultural analysis.

On the other hand, according to the Forbes ${ }^{1}$ Global leading companies list of 2019, there are four Swiss enterprises in the top one hundred listed and forty-one are in the first 2000. Swiss companies, especially the ones in banking, food processing, watch-making and pharmaceutical production, through their economic influence, play a determining role in both the global and Swiss economies. Therefore, it would not be wrong to presume that their influence will continue for some time into the future of the global business environment. A qualitative and exploratory method was conducted in the research. Thanks to their vast experience on multi-cultural awareness, this research assumed that a dialectic relation of experienced and inexperienced ones will bring a good synthesis of international management understanding and will complement each other. Therefore, Swiss managers will form the other part of the cross-cultural research addressed in this article. The main research question to be tackled is as hereby indicated: "How do management approaches differentiate in Turkish and Swiss Companies?

\section{Organizational Culture in Turkish Companies}

The military has been an important factor in Turkish social and political history ever since the age of the Ottoman Empire. This sector has had a big influence on the progress of social and organizational structures of modern Turkey as well (Heper, 2001). The Janissary Corps, as one of the most outstanding divisions of the Ottoman army and royal guards of the sultan, eventually became so influential that they could change the sovereign through military coups in case they were not content with imperial policies. After the abolition of this military force, The Committee of

${ }^{1}$ https://www.forbes.com/global2000/list/\#country:Switzerland Accessed 10 November 2019. 
Union and Progress ${ }^{2}$ challenged the sultan's absolutist power and transformed the political system of the empire from an absolute monarchy to a constitutional one. Due to their military dominance, the sultan acceded to their demand of sharing his power with them while governing the state between 1908 and 1918. After the demise of the Ottoman Empire, with the leadership of Mustafa Kemal Atatürk (in office 1923-1938), the Turkish Republic was established and since then Turkish generals have held rather important positions in statecraft. In this period, the Turkish Republic has seen three military coups: 1960, 1971 and 1980. This highly influential military tradition of Turkish political history also came to affect the characteristics of Turkish companies and as a result hierarchy became a powerful element in the organizational culture of Turkish companies (Acar, 2012; Albayrak \& Albayrak, 2014; Matej, Marko, Škerlavaj, Aydinlik, \& Polat, 2012; Nisanci, 2012; Trompenaars \& Hampden-Turner, 1999). Hierarchical organizational structure affects the relationship between superiors and subordinates. Superiors frequently play one group against the other, do not encourage participation of subordinates in the decision-making process, and show reluctance in sharing power. In addition, managers utilize control as an effective element while providing efficiency in the formalized and structured work environment (Cameron \& Quinn, 1999).

On the other hand, according to the findings of Hofstede (1980), Turkish companies' organizational culture is based on collectivism; this finding is also consistent with those of House Hanges, Javidan, Dorfman, and Gupta (2004), Kabasakal \& Bodur (1998), Matej et al. (2012), Ozturk (1997), Pasa, Kabasakal, and Bodur (2001), Trompenaaars and Hampden-Turner (1999), Yetim and Yetim (2006). Family values, such as taking care of each other and being loyal, gain more importance in collectivist cultures. Due to the impact of collectivist culture, Trompenaars and Hampden-Turner (1999) defined the category of Turkish organizations as family-types. Kabasakal and Bodur (1998) and Giritli, Yazıcı, Oraz, and Acar (2013) upheld this definition and attributed this finding to the interdependent relationship between the state and Turkish business sectors. In the family type organization, superiors are seen as mother and father figures who take care of their subordinates' welfare. Position, education level, authority and age are accepted as the most important attributes for gaining respect in the work environment (Cavusgil, Civi, Tutek, \& Dalgic 2003).

After Turkey's full membership candidature status at the European Union in 1999, the Turkish modernization process gained more acceleration while greater social reforms and democratic implementations were put into force in society. Moreover, the Turkish economy began to grow and become more integrated with the European economic market. In this context, organizational cultures of Turkish companies were influenced by human- oriented management approaches which gained popularity and subordinates began to feel freer to participate in organizational decisionmaking systems (Erturk, 2008).

In addition, after 2000, the Turkish government allotted great importance to the privatization process, and to this effect, the Turkish state's impact on the private sector began to diminish. Thereafter, Turkish companies adapted themselves to the global competition environment through

\footnotetext{
${ }^{2}$ The Committee of Union and Progress was the continuation of young Turks movement and their members were
} mostly from Army. 
preferring short-term contracts based on work performance, seeking quality of workforce and providing competitive higher salaries (Say, Toker, \& Kantur, 2008).

\section{Organizational Culture of Swiss Companies}

Swiss companies have rather strong organizational cultures that are based on long years of practice. As Swiss society and the Swiss business environment were developing, Swiss organizational culture was influenced and shaped by this progress. To this effect, in order to understand Swiss organizational culture, historical and political perspectives gain importance in the literature review.

Even though Switzerland has been a neutral state since 1515, there exists an undeniable impact from military life on Swiss social and organizational lifestyle. Military service is obligatory for men between the ages of 19 and 34 in Switzerland. A good record in military service had been a necessary criterion for the promotion of men as executives in Swiss banks and organizational structures of banks had been strongly influenced by a military hierarchical structure until the 1990s. After the entry of foreign banks to Switzerland in 1991, beginning with the Crédit Suisse, Swiss banks devolved into less hierarchical structures (Tixier, 1994). They fulfilled the spearhead role amongst other Swiss institutions, and thus, this transformation process also influenced other Swiss enterprises. Nowadays, it is very common to see less hierarchical organizational structures and more horizontal interaction between management and employees in Swiss companies. While working conditions such as working hours or salary, amongst other factors, are eminent, negotiations are the most determinant factor in many Swiss companies (Merrien \& Becker, 2005).

In addition to the military influence, religion is another important factor in the development of Swiss organizational culture. Calvinism has exerted much influence on Swiss companies' work ethic and values (Weber, 1978; Weibler \& Wunderer, 2007). Working hard, reaching higher levels of achievement and encouragement for ever-greater investments are the main values and ethical characteristics reflected on the Swiss company culture based on Calvinist belief.

In order to reach higher levels of achievement, Swiss companies do not hesitate to compete in international markets (Becker \& Schwartz, 2005). They mainly utilize "brand reputation" as their fundamental element while conducting international competition. To manage brand reputation, they prefer to reinforce the "Swiss Quality" label through enhancing their standards rather than discovering new markets (Bergmann, 1990; Weibler \& Wunderer, 2007). Competition is not only commonly used in the international arena but also inside their organizations. Even though Swiss companies pay high wages to their employees, they prefer not to make long-term contracts with them. The period of contracts ranges from 12 to 36 months (Merrien \& Becker, 2005). It is obvious that this employment policy encourages competition inside Swiss companies. Yet this highly competitive environment does not hinder standardization of skills. According to findings of Hofstede, Hofstede, and Minkov (2010), apprentice systems which encourage professional qualification and solidarity of employees are pretty common in Swiss companies.

\section{Leadership in Turkish Companies}

Turkish managers have been greatly influenced by their society's dynamics. After Turkey's existential war for independence, the Turkish Republic was established in lieu of the defunct Ottoman Empire in 1923. The Ottoman Empire was an Islamic sultanate that ruled over vast expanses of territory in Asia, Africa, Europe, and the Caucasus, for more than six hundred years. The ruler of the Ottoman Empire was referred to as the Sultan. Most of the time, the Sultan also 
was Caliph of Islam and was considered as the representative of God on earth and thereby his orders had to be adhered to without question and with immediate effect. When Mustafa Kemal Atatürk, the leader of Turkey's war of Independence and first elected president of the modern state, established the Turkish Republic, he altogether abandoned the Islamic monarchic management system. He transformed Turkey into a secular democratic republic and started a Turkish revolution with the goal of rapid modernization of society and the economy (Inalcik, 1992). In line with this goal, Turkey turned its face towards the West and aimed to become a member of Western Civilization. As referred to earlier in this section, after the passing of Atatürk, the budding Turkish democracy was interrupted by three military coups in 1960, 1971 and 1980. However, since that period, Turkish democracy has managed to overcome hard periods and has resolved to emulate Western democracies with all their institutions.

Esmer (1997) has conducted research regarding leadership types of Turkish managers. According to his findings, Turkish leaders have a tendency to demonstrate characteristics of autocratic and paternalistic types of leadership. A paternalistic leader acts like a father who protects and takes care of his followers and their families (Javidan, 2004). Correspondingly, a leader expects loyalty and absolute obedience from followers (Koksal, 2011). House et al. (2004) supported the findings of Esmer: Turkish managers have defined ideal leadership attributes as "decisive, visionary, team integrator, collaborative, team oriented, inspirational, of integrity, diplomatic and administratively competent" (Kabasakal \& Bodur, 1998, p. 852). This definition hints at the ideal type of Turkish leadership as being "charismatic" and "team-oriented", but in reality, is different than what seems to be ideal, the findings of House et al. (2004) demonstrate that Turkish leaders seem to mostly follow autocratic, non-participatory and paternalistic leadership styles.

Hofstede (2001) also made similar findings regarding Turkish leaders: They expected more privileges than subordinates at work, seem mostly inaccessible and are reluctant to share their power. Therefore, Turkish leaders practice mostly autocratic and paternalistic types of leadership. At this juncture, it is necessary to provide a definition for autocratic and paternalist leadership styles. Both of these leadership approaches tend not to want to share or delegate power and show no tolerance to be interrogated by subordinates. Yet, unlike autocratic leadership, paternalistic leadership tries to imitate a family atmosphere at the work environment through involving itself in its followers' individual problems (Pasa et al., 2001). As a result of this approach, the obedience of the follower becomes more sincere under paternalistic leadership than autocratic leadership (Aycan, 2001; Koksal, 2011).

Aycan et al. (2000) made a cross-cultural analysis about the impact of culture on human resource practices in ten countries ${ }^{3}$. In this research, Turkish managers scored in the second-highest ${ }^{4}$ bracket $^{4}$ on their perceptions of paternalism. In addition, Pellegrini and Scandura (2006) investigated the impact of paternalistic Turkish leadership behavior on job satisfaction in Turkish contexts. According to their findings, managerial paternalistic behavior would contribute positively to the job satisfaction of employees.

In Turkish culture, if someone is even two or three years older than another person, they expect to be referred to as Ağabey (older brother) or Abla (older sister) by younger siblings. That is considered to be an accepted sign of respect. Likewise, to be a parent or grand-parent directly

\footnotetext{
${ }^{3}$ Turkey, Canada, USA, Romania, Germany, Israel, Russia, China, Pakistan and India.

${ }^{4}$ India received the highest score.
} 
carries respect in Turkish society. As a duty for being Ağabey/Abla or even parents, one is expected to protect the minors in their family as well. Accordingly, the reflection of this social attitude affects, and is easily visible in Turkish leaders' attitudes. Consequently, the above-mentioned findings of researchers are rather consistent with social dynamics present in Turkey.

The Turkish Republic and the European Community entered upon a customs union on 31 December 1995 and since 12 December 1999 Turkey has been a candidate for full membership in the European Union. What is more, Turkey's economy has been flourishing ever since that period and as a consequence of this economic growth, Turkish enterprises have managed to increase economic relations with Western companies. Economic crises in Europe have also had a hand in amplifying this process while as a result a number of Turkish institutions have been able to purchase various prominent European enterprises ${ }^{5}$ and as a consequence gained an important position in Europe's markets. As a result of this promising state of economic affairs and Westernization of the traditional Turkish system, Turkish leaders' work values were also affected. Since the turn of this century, Turkish leaders' work values have begun to show more similarities to Western managerial work values. These similarities are also supported by the findings of Askun, Oz, and Askun (2010) who conducted a research project with the participation of 1022 Turkish leaders from different private industrial companies. The findings of this study point to the following ten values as most important: integrity, working with care and discipline, achievement, valuing competency, responsibility, industriousness, justice, sharing knowledge, valuing individual rights and freedom, and valuing work details, most of these values being held in common with Western managerial values (Ibid.).

\section{Leadership in Swiss Companies}

Leadership qualities are not isolated issues from the society and nation from which the leader originates. Some leadership issues have been studied in a number of cross-cultural research such as by Hofstede (1980) and House et al. (2004). According to Hofstede (1980), highly individual Swiss cultural characteristics reflect on the relationship of leaders and followers. Their relations are based on mutual benefits such as a contract. In addition, it is expected that the leader's decision for promotion or assignment must be rationalized through objectively fair criteria rather than subjective choices.

The other important cross-cultural research project, the GLOBE study, indicates that Swiss understanding of outstanding leadership is a mixture of personal traits and behaviors such as integrity, performance orientation, decisiveness, modesty, autonomous capacity, behaving inspirationally, visionary flair, administrative competence, and diplomacy (Weibler \& Wunderer, 2007). These traits and behaviors are accepted by a majority of the Swiss population and the reflection of these attributes can be observed in the dynamics of Swiss society. For example, being honest, modest, and hardworking are traits greatly encouraged in Calvinist ideology. Switzerland, as one of the main hubs of diplomacy, hosts many diplomatic organizations such as the European bureau of the United Nations, the headquarters of the World Trade Organization, the Office of the International Red Cross, and the International Labour Organisation, amongst many others. In addition, Switzerland adheres to strict democratic principles and for many decisions relating to the public sphere, relies on consensus, referenda and negotiations. In conclusion, it suffices to deduce

\footnotetext{
${ }^{5}$ Yildiz holding (Ulker group) purchased Belgian Godiva Chocolatier in 2007 and British United Biscuits in 2014.
} 
that the main forms of Swiss leadership styles would fall under participatory, democratic and nonauthoritarian categories (Brodbeck et al., 2000; Dickson, Hartog, \& Mitchelson, 2003; Dorfman \& House, 2004; Jago et al., 1993; Koopman, Den Hartog, \& Konrad, 1999; Szabo, Reber, Weibler, Brodbeck, \& Wunderer, 2001; Weibler \& Wunderer, 2007).

It should be noted that the Swiss managerial approach underwent an evolution after the 1990s. Swiss managers were highly influenced by a military-style of management and followed more authoritarian approaches in leading followers before the 1990s. Nevertheless, due to the impact of the arrival of foreign companies in the country after this period (Tixier, 1994), and the culture of democracy which merged with that of Swiss daily life, society in general began to assign more importance to consensus for arriving at decisions regarding issues related to relations with other people. These social changes reflected on Swiss leaders' behavior. As mentioned above, nowadays, Swiss managers practice democratic and participatory types of leadership.

\section{Motivation of Multi-Cultural Workforce in Turkish Companies}

Motivation tools and strategies of Turkish companies have mostly developed in the axis of organizational performance. Here, the question of "how to motivate employees" has mostly been studied from this perspective: how to increase organizational performance in Turkish companies. (Say et al., 2008; Zehir, Ertosun, Zehir, \& Mucedelli, 2011). Performance related reward systems based on increasing competition among workers, such as pay raises and bonuses in accordance with efficacy, have been utilized by Turkish companies (Nisanci, 2012; Sayim, 2010). On the other hand, the financial reward approach has not been seen as enough on its own and social and physical factors such as showing respect, giving promotions and commendation letters, have also been extensively utilized by Turkish companies as motivational tools (Sahin, 2004). Due to the importance of performance and social acceptance by others in the work environment, McClelland's need for achievement and Maslow's need for esteem have gained wide popularity as relates to motivational research vis-à-vis Turkish Companies. While the main characteristics of McClelland's need of achievement is challenging complex issues, setting objectives, and receiving feedback on success levels, Maslow's need of esteem is about self-confidence, deserved respect from others, recognition, and achievement. Turkish enterprises have seen motivation in a holistic perspective and have not developed special motivation tools for foreign employees.

If foreign employees fail to speak Turkish, they could face various problems in their daily lives while living in Turkey. This is because Turkish is the official language of the country and necessary for administrative and general purposes. Generally, young and middle-aged folks speak English, and except for tourist places, English is not very commonly spoken in Turkey. This condition is not only true for general life on the streets, but it is also the case regarding family type institutions, and even amongst old Turkish senior-level managers and employees. As Gultekin (2011) pointed out, the inability to speak Turkish by foreign employees negatively affects their motivation at work. On the other hand, the ability to share one's thoughts in the work environment positively affects the motivation levels of foreign employees. Nevertheless, except for these findings, there is no specific research in the existing literature which investigates foreign employees' motivation in Turkish companies. 


\section{Motivation of Multi-Cultural Workforce in Swiss Companies}

Work motivation is not a new phenomenon for Swiss companies. Motivation strategies and tools have been seen as inseparable components of Swiss organizational management's understanding. Mostly extrinsic motivation tools such as salary, bonuses and promotions, have been utilized for outstanding work performance by Swiss companies since the 1990s (Biget, Varone, Giauque, \& Ritz, 2010; Frey \& Goette, 1999; Salamin, 2000).

Ever since the beginning of this century, it has been assumed that if group motivation is increased, individual motivation of employees would also be enhanced; therefore, group dynamics have gained importance in the process of motivation (Arvanitis, 2005; Hertel, 2000; Staeheli, 2003). In order to improve group dynamics, competition has been utilized as one of the main approaches by Swiss companies (Jenewein \& Morhart, 2008). Creating competition is a closely related issue to Swiss economic dynamics since the economic infrastructure of competition was prepared at a macro level, seen from examples such as the liberalization of the country's public services or providing free and easy environmental access for the national market in the 1990s (Ruhli \& Schuppiseer, 1994). This policy bore fruit in the noughties and according to The Global Competitiveness Report, which was published by the World Economic Forum (WEF) in 2014, the Swiss economy has once again been chosen as the most competitive economy in the world since 2008.

In addition to having a close relation to competition, the incentive of achievement is also an important factor vis-à-vis the motivation of employees in Swiss companies. To this effect, McClelland's motivation theory - with its three motives of achievement, power and affiliation has gained popularity relative to motivational research in Swiss companies (Staeheli, 2003). By way of financial power and charming job offers, Swiss companies present rather attractive employment opportunities to foreign manpower and many foreign employees work for Swiss establishments. The need for developing motivational approaches for these employees is quite obvious. Work motivation has been viewed from holistic perspectives that may be applied to different kinds of employees in Swiss companies. In a nutshell, the comparison of the research's grand theories for both countries is presented in Table 1.

Table 1

The Comparison of Turkish and Swiss Companies

\begin{tabular}{lll}
\hline Grand theories & Turkish Companies & Swiss Companies \\
\hline & & Competitive, less hierarchical organizational \\
$\begin{array}{l}\text { Organizational Culture } \\
\text { Leadership }\end{array}$ & Family type and collectivist & structures and more negations \\
Motivation & $\begin{array}{l}\text { Paternalistic, team and human oriented } \\
\text { McClelland's need of achievement and Maslow's } \\
\text { need of esteem }\end{array}$ & $\begin{array}{l}\text { Democratic and participatory } \\
\text { McClelland's human motivation theory }\end{array}$ \\
\hline
\end{tabular}

SOURCE: Author's own work.

\section{Conclusion}

Together with Turkish society generally, Turkish managers are in the process of transformation. They aim to expand their market scale in the international arena. However, this transformation process also brings some reflections in their organizational culture. In lieu of a strict and mechanical hierarchical management structure, horizontal and human-oriented management structure has been gaining popularity. Furthermore, Turkish leaders are not only affected by Turkish social dynamics and historical developments, but also Western ideals that have had a lasting effect on their character. Hence, similar to the geographical position of Turkey itself, Turkish leaders' attributes and 
behaviors fall somewhere between Eastern and Western leadership values. From a motivational perspective, motivation of foreign employees is a new phenomenon for Turkish managers. It can be easily inferred that if Turkish managers insist on utilizing the lenses of the traditional management approach, failure is inevitable for multi-cultural work in Turkish companies.

Less-hierarchical organizational structures and more negations are important characteristics of Swiss companies, hence showing that democratic and participatory types of leadership approach will be useful in the handling of different nationalities of managers in Swiss Companies. However, findings of this research do not present different management systems or develop scientific road maps for dealing with various cultures. It emphasizes the importance of showing managerial awareness about different nationalities in the work environment. Because of their capacity for understanding different cultures, leaders who have high cultural intelligence may manage multicultural teams effectively in both Turkish and Swiss companies. As a future research area, quantitative inquiries which take into consideration generalization concerns, may be conducted to test the findings of the research in the areas of applicability.

\section{References}

Acar, A. Z. (2012). Organizational culture, leadership styles and organizational commitment in Turkish logistics industry. Procedia-Social and Behavioral Science, 58, 217-226.

Albayrak, G., \& Albayrak, U. (2014). Organizational culture approach and effects on Turkish construction sector. Apcbee Procedia, 9, 252-257.

Arvanitis, S. (2005). Computerization, workplace organization, skilled labour and firm productivity: Evidence for the Swiss business sector. Economics of Innovation and New Technology, 14(4), 225-249.

Askun, D., Oz, E. U., \& Askun, O. B. (2010). Understanding managerial work values in Turkey. Journal of Business Ethics, 93, $103-114$.

Aycan, Z. (2001). Paternalizm: Liderlik Anlayisina Iliskin Uc Gorgul Calisma [Paternalistic leadership]. Yönetim Araştırmaları Dergisi (Journal of Management Studies), 1(1), 11-33.

Aycan, Z., Kanungo, R. N., Mendonca, M., Yu, K., Deller, J., Stahl, G., \& Kurshid, A. (2000). Impact of culture on human resource management practices: A 10-country comparison. Applied Psychology: An International Review, 49(1), $192-221$.

Bartsch, V., Ebers, M., \& Maurer, I. (2013). Learning in project-based organizations: The role of project teams' social capital for overcoming barriers to learning. International Journal of Project Management, 31, 239-251.

Becker, U., \& Schwartz, H. (2005). Conclusion: The importance of lucky circumstances, and still the liberal-social democratic divide. In U. Becker \& H. Schwartz (Eds.), Employment 'Miracles': A critical comparison of the Dutch, Scandinavian, Swiss, Australian and Irish cases versus Germany and the US (pp. 231-249). Amsterdam: Amsterdam University Press.

Bergmann, A. (1990). National Culture. Die Unternehmung, 44, 360-370.

Biget, A. S., Varone, F., Giauque, D., \& Ritz, A. (2010). Motivating employees of the public sector: Does public service motivation matter? International Public Management Journal, 13(3), 213-246.

Brodbeck, F. C., Frese, M., Akerblom, S., Audia, G., Bakacsi, G., Bendova, H., \& ... Keating, M. (2000). Cultural variation of leadership prototypes across 22 European countries. Journal of Occupational \& Organizational Psychology, 73(1), 1-29.

Cameron, K. S., \& Quinn, R. E. (1999). Diagnosing and changing organizational culture: Based on the competing values framework. New York: John Wiley \& Sons.

Cavusgil, S. T., Civi, E., Tutek, H. H., \& Dalgic, T. (2003). Turkey. Thunderbird International Business Review, 45(4), 467479.

Dickson, M. W., Hartog, D. N. D., \& Mitchelson, J. K. (2003). Research on leadership in a cross-cultural context: Making progress and raising new questions. The Leadership Quarterly, 14, 729-768. 
Dorfman, P. W., \& House, R. J. (2004). Cultural influences on organizational leadership. In R. J. House, P. J. Hanges, M. Javidan, P. W. Dorfman, \& Gupta, V. (Eds.), Culture, Leadership, and Organizations: The GLOBE study of 62 societies (pp. 51-73). California: SAGE Publications.

Erturk, A. (2008). A trust-based approach to promote employees' openness to organizational change in Turkey. International Journal of Manpower, 29(5), 462-483.

Esmer, T. (1997). Turk kulturunun ozellikleri [Characteristics of Turkish Culture]. Radical Journal, July 27.

Frey, B. S., \& Goette, L. (1999). Does pay motivate volunteers? Working Paper No. 7, Institute for Empirical Research in Economics University of Zurich.

Giritli, H., Yazıc1, E. O., Oraz, G. T., \& Acar, E. (2013). The interplay between leadership and organizational culture in the Turkish construction sector. International Journal of Project Management, 31, 228-238.

Gultekin, Z., (2011). Management of cultural differences in multinational teams (Unpublished doctoral dissertation). Eskisehir Anatoly University, Turkey.

Hamden-Turner, C., \& Trompenaars, F. (2004). Building cross-cultural competence: How to create wealth from conflicting values, 2nd ed. West Sussex: John Wiley \& Sons.

Heper, M. (2001). The state and bureaucracy: The Turkish case in historical perspective. In A. Frazamand (ed.), Handbook of comparative and development public administration (pp. 677-686). Marcel \& Dekker Inc.

Hertel, G. (Ed.) (2000). Motivation gains in groups. Special issue of Zeitschrift für Sozialpsychologie, 31, (4). 204-220

Hofstede, G. (1980). Motivation, leadership, and organization: Do American theories apply abroad. Organizational Dynamics, 9(1), 42-63.

Hofstede, G. (2001). Culture's consequences, $2^{\text {nd }}$ edition. London: Sage Publications.

Hofstede, G., Hofstede, G. J., \& Minkov, M., (2010). Cultures and organizations, $3^{\text {rd }}$ edition., New York: McGraw-Hill Publishing.

House, R. J, Hanges, P. J., Javidan, M., Dorfman, P. W., \& Gupta, V., (2004). Culture, leadership, and organizations: The GLOBE study of 62 societies. California: SAGE Publications.

Inalcik, H. (1992). Some Remarks on the Ottoman Turkey's Modernization Process. Transfer of Modern Science and Technology to the Muslim World, 49-57.

Javidan, M. (2004). Performance orientation. In R. J. House, P. J. Hanges, M. Javidan, P. W. Dorfman, \& V. Gupta (Eds.), Culture, leadership, and organizations: The GLOBE study of 62 societies (pp. 239-281). California: SAGE Publications.

Jago, A. G., Reber, G., Bohnisch, W., Maczynski, J., Zavrel, J., \& Dudorkin, J. (1993). Culture's consequences? A seven nation of participation. Paper presented at the $24^{\text {th }}$ Annual Meeting of Decision Sciences Institute, Washington, D.C.

Jenewein, W., \& Morhart, F. (2008). Navigating toward team success. Team Performance Management, 14(1/2), $102-108$.

Kabasakal, H., \& Bodur, M. (1998). Leadership, Values and Institutions: The Case of Turkey. Research papers. Bogazici University, Istanbul, Turkey.

Koksal, O. (2011). Bir kulturel liderlik paradoksu: Paternalizm [A cultural leadership paradox: Paternalism]. Mustafa Kemal University Journal of Social Sciences Institute, 8(15), 101-122.

Koopman, P. L., Den Hartog, D. N., \& Konrad, E. (1999). National culture and leadership profiles in Europe: Some results from the GLOBE study. European Journal of Work and Organizational Psychology, 8(4), 503-520.

Kurosawa, T. (2018). Industry History: Its Concepts and Methods. In B. Bouwens, P-Y. Donzé, T. Kurosawa (Eds.), Industries and global competition: A history of business beyond borders. New York: Routledge.

Lukin, A. (2019). Russian-Chinese cooperation in central Asia and the idea of greater Eurasia, India Quarterly, 1-14.

Matej, Č., Marko, J., Škerlavaj, M., Aydinlik, A. U., \& Polat, D. D. (2012). Organizational learning culture and innovativeness in Turkish firms. Journal of Management and Organization, 18(2), 193-219.

Merrien, F. X., \& Becker, U. (2005). The Swiss miracle: Low growth and high employment. In U. Becker \& H. Schwartz (Eds.), Employment 'Miracles': A critical comparison of the Dutch, Scandinavian, Swiss, Australian and Irish cases versus Germany and the US (pp. 113-132). Amsterdam: Amsterdam University Press.

Nisanci, Z. N. (2012). Toplumsal kültür-örgüt kültürü ilişkisi ve yönetim üzerine yansımaları [Organizational culture relationship and its reflections to the management]. Batman Universitesi Yasam Bilimleri Dergisi (Batman University Journal of Life Sciences), 1(1), 1279-1293.

Ozturk, A. (1997). Yönetim-kültür ilişkisi ve Türk Işletmelerinin yönetim kültürünün tanımlanmasına ilişkin bir çalışma [Management-culture relation and a research toward defining Turkish enterprises' management culture). Yönetim (Management), 9(27), 40-52. 
Pasa, S. F., Kabasakal, H., \& Bodur, M. (2001). Society, organizations and leadership in Turkey, Applied Psychology: An International Review, 50(4), 559-589.

Pellegrini, E. K., \& Scandura, T. A. (2006). Leader-Member Exchange (LMX), paternalism and delegation in the Turkish business culture: An empirical investigation. Journal of International Business Studies, 37(2), 264-279.

Presidency of Strategy and Budged (2019). Eleventh Development Plan (2019-2023), Ankara: Presidency of the Republic of Turkey.

Ruhli, E., \& Schuppiseer, S. (1994). Switzerland and its industry in international competition. The Columbia Journal of World Business, Winter, 55-65.

Sahin, A. (2004). Yonetim kuramlari ve motivasyon iliskisi (Management theories and motivation relation). Selcuk Universitesi Sosyal Bilimler Enstitusu Dergisi (Selcuk University Social Sciences Institute Journal), 11, 523-547.

Salamin, A. (2000). Rewards characteristics and intrinsic motivation: An exploratory study on homeostatic mechanisms. Swiss Journal of Psychology, 59(1), 3-15.

Say, A. I., Toker, A., \& Kantur, D. (2008). Do popular management techniques improve performance? Journal of Management Development, 27(7), 660-677.

Sayim, K. Z. (2010). Pushed or pulled? Transfer of reward management policies in MNCs. The International Journal of Human Resource Management, 21(14), 2631-2658.

Schwartz, S. H. (1999). A theory of cultural values and some implications for work. International Association of Applied Psychology, 48(1), 23-47.

Staeheli, B. (2003). Cross-Cultural Management within Switzerland: An In-depth Case study of a Swiss Financial Services Company (Unpublished doctoral dissertation). St-Gallen University.

Szabo, E., Reber, G., Weibler, J., Brodbeck, F., \& Wunderer, R. (2001). Values and behavior orientation in leadership studies: Reflections based on findings in three German-speaking countries. Leadership Quarterly, 12(2), 219-244.

Templer, K. J., Tay, C., \& Chandrasekar, N. A. (2006). Motivational cultural intelligence, realistic job preview, realistic living conditions preview and cross-cultural adjustment. Organization Management, 31, 154-173.

Tixier, M. (1994). Management and communication styles in Europe: Can they be compared and matched. Employee Relations, $16(1), 8-26$.

Trompenaars, F., \& Hampden-Turner, C. (1999). Riding he waves of culture: Understanding cultural diversity in global business (2nd ed.) New York: McGraw - Hill.

Yetim, N., \& Yetim, U. (2006). The cultural orientations of entrepreneurs and employees' job satisfaction: the Turkish small and medium sized enterprises case. Social Indicators Research, 77(2), 257-286.

Weber, M. (1978). Economy and society. Berkeley: University of California Press.

Weibler, J., \& Wunderer, R. (2007). Leadership and culture in Switzerland. In J. S. Chhokar, F. C. Brodbeck, \& R. J. House (Eds.), Culture and leadership across the world: The GLOBE book of In-depth studies of 25 societies (pp. 251-296). New Jersey: Lawrence Erlbaum Associates Publishers.

Zehir, C., Ertosun, O., Zehir, S., \& Mucedelli, B. (2011). The effects of leadership styles and organizational culture over firm performance: Multi-national companies in Istanbul, Procedia Social and Behavioral Sciences, 24, 1460-1474. 